\title{
Aqueous Extract from Cinnamomum zeylanicum (Lauraceae) Stem Bark Ameliorates Gentamicin-Induced Nephrotoxicity in Rats by Modulating Oxidative Stress and Inflammatory Markers
}

\author{
Albert Donatien Atsamo ${ }^{(D)}{ }^{1}$ Auscar Lontsie Songmene, ${ }^{1}$ \\ Mireille Flaure Metchi Donfack $\left(\mathbb{D},{ }^{1}\right.$ Omer Bébé Ngouateu ${ }^{(D)}{ }^{1}$ \\ Télesphore Benoît Nguelefack ${ }^{D}{ }^{2}$ and Théophile Dimo ${ }^{1}{ }^{1}$ \\ ${ }^{1}$ Department of Animal Biology and Physiology, Faculty of Science, University of Yaoundé I, P.O. Box 812, Yaoundé, Cameroon \\ ${ }^{2}$ Department of Animal Biology, Faculty of Science, University of Dschang, P.O. Box 67, Dschang, Cameroon
}

Correspondence should be addressed to Albert Donatien Atsamo; atsamoalbert@gmail.com

Received 27 February 2021; Revised 29 June 2021; Accepted 10 July 2021; Published 20 July 2021

Academic Editor: Ângelo Luís

Copyright (C) 2021 Albert Donatien Atsamo et al. This is an open access article distributed under the Creative Commons Attribution License, which permits unrestricted use, distribution, and reproduction in any medium, provided the original work is properly cited.

\begin{abstract}
Nephropathies and especially nephrotoxicity have become one of the serious causes of life-threatening conditions because of intensive exposure to xenobiotic whether by environmental pollution or by drug abuse. The present study was undertaken to assess the protective effects of Cinnamomum zeylanicum stem bark aqueous extract (AECZ) on gentamicin-induced nephrotoxicity. AECZ was prepared by maceration in water and tested orally at the doses of 200 and $400 \mathrm{mg} / \mathrm{kg} / \mathrm{day}$ to prevent gentamicin-induced nephropathies in male Wistar rats. Gentamicin $(100 \mathrm{mg} / \mathrm{kg} /$ day $)$ was administered for 14 consecutive days by intraperitoneal route, concomitantly with AECZ or silymarin $(50 \mathrm{mg} / \mathrm{kg} /$ day $)$ used as reference drug. Animal body weight was monitored during the treatment. After the last treatment on the 14th day, animals were sacrificed. Blood was collected for the evaluation of hematological and renal function biomarkers. The homogenate of one kidney was used to assess oxidative stress markers and proinflammatory cytokines, while the other one was fixed in formaldehyde for histopathological studies. Gentamicin decreased body weight, serum total proteins, and calcium level but increased kidneys' relative weight, serum creatinine, urea, and uric acid. Moreover, the levels of reduced glutathione, catalase, and superoxide dismutase activities were decreased, while an increase in malondialdehyde, proinflammatory cytokines (TNF- $\alpha$, IL-1 $\beta$, and IL-6), and nitrites was observed in the negative control group as compared to normal control. Histological analysis of the kidney revealed the presence of tubular necrosis, glomerular degeneration, and macrophage infiltration in the gentamicin-treated group. All these impairment parameters were prevented by AECZ and silymarin treatments. AECZ has a protective effect against gentamicin-induced nephrotoxicity. The antioxidant and anti-inflammatory potentials of this extract may highly contribute to its nephroprotective activity.
\end{abstract}

\section{Introduction}

Drug-induced nephrotoxicity is one of the common problems in clinical medicine. Nephrotoxic medications can lead to damage to the kidney via various mechanisms, including structural and functional alterations. When evaluating the primary causes in renal injury, the incidence of drug-induced toxicity has accounted for $20 \%$ of all-cause incidents $[1,2]$. Many drugs, including gentamicin (GM), are nephrotoxic. Gentamicin is an aminoglycoside antibiotic agent that is widely used in clinical practice for the treatment of Gram-negative infection [3]. However, 10 to $30 \%$ of patients subjected to this drug have high risk of developing renal dysfunction mainly after long-term treatment $[1,2]$. Renal injury induced by gentamicin is related to its preferential accumulation in the renal proximal convoluted tubules, which leads to loss of brush border integrity [4]. Mechanisms of GM-induced nephrotoxicity comprise free radicals generation, increase lipids peroxidation, and decrease activity of endogenous antioxidant, renal inflammation 
characterized by macrophage infiltration, and subsequent release of proinflammatory cytokines associated with the activation of the stress-induced NF- $\kappa \mathrm{B}$, acute tubular necrosis, and glomerular congestion, resulting in diminished glomerular filtration rate and renal dysfunction [5-7]. Several approaches have been tried to reduce gentamicin nephrotoxicity by using various natural antioxidants, such as the use of Moringa oleifera seeds, Rosmarinus officinalis, and Thymus vulgaris $[8,9]$. This is due to their effectiveness, minimal side effects in clinical use, and relatively low costs. Herbs have many phytochemicals which possess antioxidant activity and can be promising agents against gentamicin toxicity.

Cinnamomum zeylanicum (Lauraceae), also known as true cinnamon, which originates from Sri Lanka and south India, is a tree that is about 10 meters high and can withstand hard climatic conditions. It is found predominantly in tropical and subtropical regions, where the rainfall and the temperature range from $1500 \mathrm{~mm}$ to $2500 \mathrm{~mm}$ and from $27^{\circ} \mathrm{C}$ to $30^{\circ} \mathrm{C}$, respectively [10]. Their leaves and stem barks are important and popular spices used worldwide not only for cooking but also in traditional and modern medicines [11].

Many communities in Cameroon use the stem bark of this plant traditionally for the management of various ailments such as muscular pain, rheumatism, gastrointestinal disorders, and typhoid fever [12]. It is also used as an aphrodisiac and an antihypertensive medicine [13]. Pharmacological investigations carried out on C. zeylanicum have demonstrated its therapeutic potentials including antihypertensive and vasorelaxant activities [13], antinociceptive and anti-inflammatory effects [14], antidiabetic activity [15], immunomodulatory activity [16], and antiartherosclerotic potential against glucocorticoid-induced atherosclerosis in rat [17]. The methanol extract of Cinnamomum zeylanicum stem bark also demonstrated acute and chronic antihypertensive properties in NO-deficient hypertensive rats [18]. Recently, research has found that the aqueous extract of Cinnamomum zeylanicum stem barks can attenuate diclofenac sodium and oxytetracycline mediated hepatorenal toxicity by modulating oxidative stress, cell apoptosis, and inflammation in male albino rats [19]. Also, cinnamon oil protects kidney against acetaminophen-induced nephrotoxicity by ameliorating oxidative stress, apoptosis, and inflammation in rats [20].

The stem barks of Cinnamomum zeylanicum contain $45 \% \sim 65 \%$ cinnamaldehyde, $12 \% \sim 18 \%$ eugenol, and small amounts of $2^{\prime}$-hydroxycinnamaldehyde and 2'-benzoyloxycinnamaldehyde [21,22].

Cinnamaldehyde, a phenolic compound primarily identified as the main phytochemical found in cinnamon bark, is responsible for most of the biological effects of Cinnamomum zeylanicum [23]. Various studies have suggested that antifungal, anticancer, antimutagenic, anti-inflammatory, neuroprotective, and antioxidant effects of Cinnamomum zeylanicum are mainly due to the presence of cinnamaldehyde and eugenol $[24,25]$. It is well established that extracts and oils obtained from cinnamon have strong free radical scavenging or antioxidant activity related to the presence of flavonoids and polyphenolic compounds $[12,26]$.

Although the nephroprotective activity of the ethanolic extract of Cinnamomum zeylanicum stem barks has been demonstrated [27], no information is presently available as regards that of the aqueous extract, which is the most common form of preparation used by the population. Besides, the mechanisms by which $C$. zeylanicum protects against kidney damage are not known. The present study was undertaken to determine the preventive effect of AECZ extract in gentamicin-induced nephrotoxicity by investigating the impact of treatment on some renal biomarkers, oxidative stress parameters, proinflammatory cytokines, and histopathological features.

\section{Materials and Methods}

2.1. Plant Material and Preparation of the Extract. Cinnamomum zeylanicum parts were harvested in Njombe (Littoral Region of Cameroon) in August 2018 and used for the authentication of the plant in Yaoundé National Herbarium by comparison with the voucher specimen SRFC/ 22309. The stem barks were air-dried at room temperature and ground into a fine powder. $800 \mathrm{~g}$ of this powder was macerated into $7 \mathrm{~L}$ of distilled water for 48 hours. The mixture was then filtered with Whatman filter paper no. 3 . The filtrate was lyophilized, and $30.78 \mathrm{~g}$ of the aqueous extract was obtained from this preparation (yield of 3.85\%).

2.2. Animal Material. Thirty-six male, 8-9-week-old Wistar rats weighing between 135 and $145 \mathrm{~g}$ at the beginning of the experiment were obtained from the animal house of the Department of Animal Biology and Physiology, Faculty of Science, University of Yaoundé 1, Cameroon. They were maintained under standard laboratory conditions with natural light cycle and had free access to normal laboratory rat chow and tap water. The study was conducted in accordance with the guidelines of the Cameroon National Ethical Committee of the use of laboratory animals for scientific research (ref. NFWA-IRD 0001954).

2.3. Animals Grouping and Experimental Design. The thirtysix rats were randomized and assigned to six groups composed of six animals each and treated daily for 14 days as follows: a vehicle control group which received distilled water $(10 \mathrm{~mL} / \mathrm{kg}$, p.o. $)$ and saline solution $0.9 \%(1 \mathrm{~mL} / \mathrm{kg}$, i.p.), a negative control group which received distilled water $(10 \mathrm{~mL} / \mathrm{kg}$, p.o. $)$ and gentamicin $(100 \mathrm{mg} / \mathrm{kg}$, i.p. $)$, a positive control group which received silymarin $(50 \mathrm{mg} / \mathrm{kg}$, p.o. $)$ and gentamicin $(100 \mathrm{mg} / \mathrm{kg}$, i.p.), the two test groups which received the aqueous extract of Cinnamomum zeylanicum (AECZ) at the doses of $200 \mathrm{mg} / \mathrm{kg}$ and $400 \mathrm{mg} / \mathrm{kg}$ (p.o.) and gentamicin $(100 \mathrm{mg} / \mathrm{kg}$, i.p.), and the extract control group which was treated with AECZ ( $400 \mathrm{mg} / \mathrm{kg} /$, p.o.) and saline solution $0.9 \%(1 \mathrm{~mL} / \mathrm{kg}$, i.p. $)$. The doses of the extract were chosen from literature based on their protective effect against acetaminophen-induced cellular damage and apoptosis in renal tissue [28]. The oral administration of the 
plant extract or silymarin was performed one hour before the intraperitoneal injection of gentamicin. Body weight was recorded at the beginning and at the end of the experimental period.

At the end of the treatment on day 15, animals were fasted overnight but had free access to water. They were then anesthetized with urethane $(1.5 \mathrm{~g} / \mathrm{kg}$, i.p.) and blood from the carotid arteries was collected using capillary tubes under an anticoagulant (Ethylenediaminetetraacetate) or not, for hematological and biochemical studies, respectively. After blood collection, the rats were sacrificed by decapitation. The two kidneys were collected and dry-blotted and the relative organ weight was calculated.

\subsection{Measurement of Hematological Parameters.} Hematological analysis was performed with blood collected under EDTA using a hematimeter (Mindray BC-3000). The parameters considered were the red blood cells (RBC) count, the white blood cells (WBC) count, the hemoglobin ( $\mathrm{Hb})$ concentration, the hematocrit (HCT), the mean corpuscular hemoglobin $(\mathrm{MCH})$, the mean corpuscular volume (MCV), the mean corpuscular hemoglobin concentration (MCHC), the platelet count, the lymphocyte, the monocyte, and the granulocyte counts.

2.5. Biochemical and Histological Analysis. Serum was separated from the clotted blood sample by centrifugation $\left(1510 \times \mathrm{g}, 15 \mathrm{~min}, 4^{\circ} \mathrm{C}\right)$ and the collected sample was stored at $-20^{\circ} \mathrm{C}$ for analysis. Glucose (CN:BXC0101A), albumin

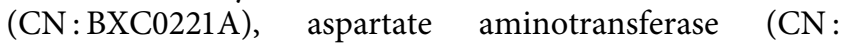
BXC0128A), urea (CN:BXC0126A), creatinine (CN : BXC0117A), uric acid (CN : BXC0603B), and total calcium (CN:BXC0292A) were assayed in serum samples, using corresponding commercial diagnostic kits purchased from Fortress, UK. Total protein was evaluated using the method of Bradford (1976). Serum $\mathrm{Na}^{+}, \mathrm{K}^{+}$, and $\mathrm{Cl}^{-}$were determined using automatic equipment (Biolyte $2000-\mathrm{Na}^{+}, \mathrm{K}^{+}, \mathrm{Cl}^{-} / \mathrm{Li}^{+}$, Diocare Corporation, Thailand).

One of the collected kidneys was homogenized at $20 \%$ (w/v) in Tris-HCl $50 \mathrm{mM}$ buffer ( $\mathrm{pH}$ 7.4). The obtained homogenates were centrifuged at $1510 \times \mathrm{g}$ for 15 minutes at $4^{\circ} \mathrm{C}$. The supernatant collected was stored at $-20^{\circ} \mathrm{C}$ for further biochemical assays. The total protein was determined by the method of Bradford [29]. The superoxide dismutase (SOD) activity was assessed according to Misra and Fridovich. Reduced glutathione (GSH) and catalase were assayed following the method described by Ellman [30] and Sinha [31], respectively. Nitrites' content was estimated as described by Slack [32], while malondialdehyde (MDA) was determined by the method described by [33].

The levels of the inflammatory cytokines, interleukin- $1 \beta$ (IL-1 $\beta$ ), IL-6, and tumor necrosis factor- $\alpha$ (TNF- $\alpha$ ), in kidney homogenate were measured using a Sandwich enzyme-linked immunoassay kits specific to each cytokine (R\&D Systems, USA). The measurements were performed at $450 \mathrm{~nm}$ using a microplate-reading spectrophotometer (Thermo Scientific Multiskan FC). The levels of TNF- $\alpha$, IL$1 \beta$, and IL-6 were expressed as $\mathrm{pg} / \mathrm{mg}$ of protein [34].
For histological analysis, the second kidney was fixed in $10 \%$ formalin for 7 days and further paraffin-embedded. Sections of $4-5 \mu \mathrm{m}$ were made and further stained with hematoxylin and eosin (H\&E). The sections were examined with light microscope (Zeiss Axioscope) and digital camera, and MiniSee software was used for images capture. As an example of kidney damage, tubular clarifications were quantified using ImageJ software, version 1.48 for Windows. The percentage of tubular clarifications was calculated as follows:

$\%$ tubular clarification $=\left(\frac{\text { tubular clarification count }}{\text { total tubular count }}\right) \times 100$.

2.6. Statistical Analysis. Data were expressed as mean\pm standard error of mean. Statistical analysis was performed using one-way analysis of variance (ANOVA) followed by the Tukey post hoc test. $p<0.05$ was considered statistically significant. All analyses were performed using GraphPad Prism software, version 8.01.

\section{Results}

3.1. Effect of C. zeylanicum on the Body Weight and Relative Kidney Weight. Gentamicin significantly $(p<0.001)$ decreased the rat weight gain by $45.93 \%$ and increased the relative kidney weight by $48.34 \%$ as compared to normal control group. AECZ at the doses of 200 and $400 \mathrm{mg} / \mathrm{kg}$ significantly $(p<0.001)$ prevented the decrease of weight gain and the increase of relative kidney weight by $14.13 \%$ and $17.39 \%$, respectively, compared to gentamicin group. AECZ administered alone significantly increased the body weight gain as compared to normal control (Table 1).

\subsection{Effects of C. zeylanicum Stem Bark Aqueous Extract on} Hematological Parameters. Table 2 shows the effects of AECZ on some hematological parameters. Apart from the number of monocytes, no other hematological parameter varied significantly regardless of the treatment received. Gentamicin significantly decreased by $52.95 \%(p<0.001)$ the number of monocytes compared to the normal control. Silymarin $(50 \mathrm{mg} / \mathrm{kg})$ and AECZ at the doses of 200 and $400 \mathrm{mg} / \mathrm{kg}$ significantly increased the number of monocytes by $52.50 \%(p<0.05), 90 \%(p<0.001)$, and $67.50 \%(p<0.01)$, respectively, compared to the group treated only with gentamicin.

\subsection{Effects of the Aqueous Extract of C. zeylanicum Stem Barks} on Serum Glucose, Albumin, Total Protein, and Aspartate Aminotransferase. The effect of AECZ on serum glucose, total proteins, albumin, and aspartate aminotransferase (ASAT) is presented in Table 3. Consecutive to gentamicin administration, a significant decrease of proteinemia (25\%) as compared to normal control was observed. Compared to GM group, AECZ at the doses of $200 \mathrm{mg} / \mathrm{kg}$ and $400 \mathrm{mg} / \mathrm{kg}$ significantly inhibited the decrease of proteinemia by $17.30 \%$ 
TABLE 1: Effects of C. zeylanicum stem bark aqueous extract on body weight and kidney's relative weight.

\begin{tabular}{|c|c|c|c|c|c|c|}
\hline & NC & GM & Sily $50+$ GM & AECZ $200+$ GM & AECZ $400+$ GM & AECZ 400 \\
\hline BW & $6+8 s$ & $143.33 \pm 1$ & $134.33 \pm 8.81$ & $139.00 \pm 10.41$ & $140.33 \pm 5.91$ & $140.66 \pm 7.81$ \\
\hline BW & 79.88 & 78 & 17 & 1 & 178 & $=4.13$ \\
\hline$\Delta \mathrm{BW}$ & $29.24 \pm 1.49$ & $15.81 \pm 0.48^{\mathrm{z}}$ & $33.03 \pm 1.11^{\mathrm{c}}$ & $39.05 \pm 2.64^{\mathrm{c}}$ & $33.66 \pm 2.07^{\mathrm{c}}$ & $40.51 \pm 1.13^{z}$ \\
\hline Kidney's relative weight (g/100 g BW) & $0.62 \pm 0.01$ & $0.92 \pm 0.01^{\mathrm{Z}}$ & $0.72 \pm 0.01^{\mathrm{c}}$ & $0.79 \pm 0.01^{\mathrm{c}}$ & $0.76 \pm 0.02^{\mathrm{c}}$ & $0.67 \pm 0.01$ \\
\hline
\end{tabular}

Each value represents the mean \pm SEM. $n=6 ;{ }^{\mathrm{z}} p<0.001$ indicates significant difference as compared to normal control. ${ }^{c} p<0.001$ indicates significant difference as compared to negative control. $\mathrm{BW}=$ body weight, $\Delta \mathrm{BW}=$ variation of body weight, $\mathrm{D}=$ day, $\mathrm{NC}=$ normal control, $\mathrm{GM}=$ gentamicin, $\mathrm{AECZ}=$ stem barks aqueous extract of Cinnamomum zeylanicum, and Sily $50=$ silymarin $(50 \mathrm{mg} / \mathrm{kg})$.

TABle 2: Effects of C. zeylanicum stem bark aqueous extract on some hematological parameters.

\begin{tabular}{|c|c|c|c|c|c|c|}
\hline Parameters & NC & GM & Sily $50+$ GM & AECZ $200+\mathrm{GM}$ & AECZ $400+$ GM & AECZ 400 \\
\hline WBC $\left(\times 10^{3} / \mu \mathrm{L}\right)$ & $6.30 \pm 0.67$ & $5.26 \pm 0.71$ & $6.01 \pm 0.94$ & $7.25 \pm 0.89$ & $6.15 \pm 0.87$ & $6.20 \pm 0.49$ \\
\hline Lympho $\left(\times 10^{3} / \mu \mathrm{L}\right)$ & $3.51 \pm 0.22$ & $2.68 \pm 0.28$ & $3.44 \pm 0.51$ & $4.00 \pm 0.55$ & $3.97 \pm 0.49$ & $3.47 \pm 0.38$ \\
\hline Mono $\left(\times 10^{3} / \mu \mathrm{L}\right)$ & $0.85 \pm 0.03$ & $0.40 \pm 0.04^{\mathrm{z}}$ & $0.61 \pm 0.03^{\mathrm{a}}$ & $0.76 \pm 0.06^{\mathrm{c}}$ & $0.67 \pm 0.06^{\mathrm{b}}$ & $0.61 \pm 0.05$ \\
\hline Granulo $\left(\times 10^{3} / \mu \mathrm{L}\right)$ & $1.45 \pm 0.17$ & $1.44 \pm 0.11$ & $1.15 \pm 0.20$ & $1.45 \pm 0.20$ & $1.24 \pm 0.15$ & $1.56 \pm 0.08$ \\
\hline $\mathrm{RBC}\left(\times 10^{6} / \mu \mathrm{L}\right)$ & $6.92 \pm 0.14$ & $6.77 \pm 0.28$ & $7.02 \pm 0.10$ & $7.09 \pm 0.12$ & $6.82 \pm 0.18$ & $6.88 \pm 0.24$ \\
\hline PLT $\left(\times 10^{3} / \mu \mathrm{L}\right)$ & $472.6 \pm 7.6$ & $466.6 \pm 46.6$ & $458.1 \pm 48.2$ & $522.8 \pm 48.2$ & $457.5 \pm 32.1$ & $29.5 \pm 35.7$ \\
\hline $\mathrm{Hb}(\mathrm{g} / \mathrm{dL})$ & $13.31 \pm 0.18$ & $12.93 \pm 0.64$ & $13.25 \pm 0.35$ & $13.91 \pm 0.20$ & $12.53 \pm 0.51$ & $13.01 \pm 0.54$ \\
\hline HTC (\%) & $36.41 \pm 1.41$ & $34.41 \pm 2.55$ & $34.86 \pm 1.85$ & $36.50 \pm 1.53$ & $33.916 \pm 1.09$ & $35.65 \pm 2.35$ \\
\hline $\operatorname{MCV}(\mathrm{fL})$ & $52.83 \pm 2.56$ & $50.70 \pm 2.73$ & $49.95 \pm 2.48$ & $53.60 \pm 2.73$ & $52.75 \pm 2.24$ & $51.97 \pm 3.07$ \\
\hline $\mathrm{MCH}(\mathrm{pg})$ & $19.22 \pm 0.39$ & $19.02 \pm 0.46$ & $18.83 \pm 0.40$ & $19.95 \pm 0.57$ & $19.30 \pm 0.28$ & $18.88 \pm 0.52$ \\
\hline $\operatorname{MCHC}(\mathrm{g} / \mathrm{dL})$ & $36.73 \pm 1.12$ & $37.92 \pm 1.14$ & $37.98 \pm 1.24$ & $38.37 \pm 1.21$ & $36.92 \pm 1.17$ & $36.82 \pm 1.30$ \\
\hline
\end{tabular}

Each value represents the mean \pm SEM. $n=6 ;{ }^{\mathrm{z}} p<0.001$ indicates significant differences as compared to normal control; ${ }^{\mathrm{a}} p<0.05,{ }^{\mathrm{b}} p<0.01$, and ${ }^{\mathrm{c}} p<0.001$ indicate significant differences as compared to the gentamicin group. NC: normal control, GM: gentamicin, AECZ: stem barks aqueous extract of Cinnamomum zeylanicum, Sily 50: silymarin $(50 \mathrm{mg} / \mathrm{kg})$, WBC: white blood cells, Lympho: lymphocytes, Mono: monocytes, Granulo: granulocytes, RBC: red blood cells, Hb: hemoglobin, PLT: platelets, HTC: hematocrit, MCH: mean corpuscular hemoglobin, MCV: mean corpuscular volume, and MCHC: mean corpuscular hemoglobin concentration.

$(p<0.05)$ and $23.07 \%(p<0.01)$, respectively. In the GM group, the serum concentration of albumin increased significantly by $15.91 \%(p<0.001)$ compared to normal control group, but concomitant treatment with GM and AECZ at the doses of 200 and $400 \mathrm{mg} / \mathrm{kg}$ significantly $(p<0.001)$ reduced the serum albumin by 12.83 and 13.73 , respectively. The serum concentration of aspartate aminotransferase increased significantly by $57.7 \%(p<0.001)$ in the GM group when compared to normal control. The administration of C. zeylanicum extract at the doses of 200 and $400 \mathrm{mg} / \mathrm{kg}$ or silymarin $(50 \mathrm{mg} / \mathrm{kg})$ resulted in a significant reduction in ASAT activity, respectively, by $52.71 \%(p<0.01), 64.70 \%$ $(p<0.001)$, and $53.38 \%(p<0.01)$ as compared to gentamicin-intoxicated rats. None of the evaluated parameters were affected by AECZ when administered alone.

3.4. Effects of the Aqueous Extract of C. zeylanicum Stem Barks on Some Kidney Biomarkers and Electrolytes. The effects of AECZ on kidney's function were evaluated by determining the rate of creatinine, uric acid, urea, and electrolytes (calcium, potassium, sodium, and chloride ions) in serum (Table 4). Gentamicin significantly increased serum creatinine by $77.72 \%$, urea by $131.14 \%$, and uric acid by $123.03 \%$ and decreased calcium level by $56.56 \%$ as compared to normal control. In comparison to negative control group, the two doses of AECZ $(200 \mathrm{mg} / \mathrm{kg}$ and $400 \mathrm{mg} / \mathrm{kg})$ significantly $(p<0.001)$ inhibited the increase of serum creatinine by $43.72 \%$ and $47.16 \%$, urea by $57.08 \%$ and $47.16 \%$, and uric acid by $57.08 \%$ and $47.16 \%$, respectively. AECZ at the doses of
$200 \mathrm{mg} / \mathrm{kg}$ and $400 \mathrm{mg} / \mathrm{kg}$ also prevented the decrease of calcium level by $122.48 \%$ and $116.06 \%$, respectively. Likewise, silymarin also prevented this decrease. The serum levels of potassium and sodium were not significantly affected by any of the treatments as compared to normal control.

3.5. Effects of the Aqueous Extract of C. zeylanicum Stem Barks on Renal Oxidative Stress Parameters. The effects of the aqueous extract of C. zeylanicum stem barks on some kidney markers of oxidative stress are shown in Figure 1. The renal activity of SOD in the negative control decreased significantly $(p<0.001)$ by $73.79 \%(10.3 \pm 1.14)$, compared with the normal control group $(39.3 \pm 5.05)$. However, pretreatment with silymarin $(50 \mathrm{mg} / \mathrm{kg})$ and AECZ $(200 \mathrm{mg} / \mathrm{kg}$ and $400 \mathrm{mg} / \mathrm{kg})$ significantly $(p<0.001)$ enhanced superoxide dismutase concentration by about $300.97 \%, 406.79 \%$, and $377.66 \%(41.30 \pm 4.45,52.20 \pm 3.78$, and $49.20 \pm 4.23$, respectively) compared with the gentamicin group $(10.30 \pm 1.14)$.

Treatment with GM induced a significant decrease $(p<0.001)$ in the renal activity of CAT $(68.60 \pm 2.89)$ as compared to normal control rats $(168.00 \pm 11.00)$. Silymarin $(50 \mathrm{mg} / \mathrm{kg})$ significantly increased $(p<0.001)$ the activity of CAT in the kidneys by $76.38 \%$ as compared to the GM group $(121.00 \pm 12.7$ versus $68.60 \pm 2.89)$. AECZ at the doses of $200 \mathrm{mg} / \mathrm{kg}$ and $400 \mathrm{mg} / \mathrm{kg}$ significantly enhanced CAT concentration in a dose-dependent manner by about $57.43 \%$ $(108.00 \pm 3.33)$ and $86.58 \%(128.00 \pm 7.91)$ compared to gentamicin group $(68.60 \pm 2.89)$. 
TABLE 3: Effects of C. zeylanicum stem bark aqueous extract on serum glucose, total proteins, albumin, and aspartate aminotransferase.

\begin{tabular}{|c|c|c|c|c|c|c|}
\hline Parameters & $\mathrm{NC}$ & GM & Sily $50+$ GM & AECZ $200+\mathrm{GM}$ & AECZ $400+\mathrm{GM}$ & AECZ 400 \\
\hline Tota & $130 \pm 0.02$ & $104 \pm 0.01^{\mathrm{y}}$ & $120 \pm 0.01^{\mathrm{a}}$ & $122 \pm 0.01^{\mathrm{a}}$ & $128 \pm 0.03^{\mathrm{b}}$ & .04 \\
\hline $\mathrm{Alb}$ & 57.80 & 67.00 & $57.50 \pm 1.28^{\mathrm{c}}$ & $58.40 \pm 1.01^{\mathrm{c}}$ & $57.80 \pm 0.84^{\mathrm{c}}$ & .49 \\
\hline $\mathrm{lg} / \mathrm{dL})$ & 7 & & $71.99 \pm 6.37$ & $73.60 \pm 7.21$ & $67.58 \pm 3.63$ & \pm 6.09 \\
\hline ASAT (UI) & $172.54 \pm 32.43$ & $407.81 \pm 79.83^{z}$ & $190.11 \pm 27.84^{\mathrm{b}}$ & $192.85 \pm 23.56^{\mathrm{b}}$ & $143.99 \pm 20.18^{\mathrm{c}}$ & $148.94 \pm 7.08$ \\
\hline
\end{tabular}

Each value represents the mean \pm SEM. $n=6 ;{ }^{\mathrm{y}} p<0.01$ and $^{\mathrm{z}} p<0.001$ indicate significant difference as compared to normal control. ${ }^{\mathrm{a}} p<0.05$, ${ }^{\mathrm{b}} p<0.01$, and ${ }^{c} p<0.001$ indicate significant differences as compared to negative control. $\mathrm{NC}=$ normal control, $\mathrm{GM}=$ gentamicin, $\mathrm{AECZ}=$ stem barks aqueous extract of Cinnamomum zeylanicum, Sily $50=$ silymarin $(50 \mathrm{mg} / \mathrm{kg})$, and ASAT $=$ aspartate aminotransferase.

TABle 4: Effects of C. zeylanicum stem bark aqueous extract on some renal function biomarkers and electrolytes.

\begin{tabular}{|c|c|c|c|c|c|c|}
\hline Parameters & $\mathrm{NC}$ & GM & Sily $50+$ GM & AECZ $200+\mathrm{GM}$ & AECZ $400+\mathrm{GM}$ & AECZ 400 \\
\hline Creatinine $(\mathrm{mg} / \mathrm{dL})$ & $0.57 \pm 0.02$ & $1.02 \pm 0.09^{\mathrm{z}}$ & $0.35 \pm 0.05^{\mathrm{c}}$ & $0.57 \pm 0.04^{\mathrm{c}}$ & $0.55 \pm 0.03^{\mathrm{c}}$ & $0.51 \pm 0.05$ \\
\hline Urea $(\mathrm{mg} / \mathrm{dL})$ & $21.80 \pm 1.73$ & $50.39 \pm 3.56^{\mathrm{z}}$ & $20.89 \pm 1.54^{\mathrm{c}}$ & $26.49 \pm 2.55^{\mathrm{c}}$ & $21.69 \pm 2.31^{\mathrm{c}}$ & $25.13 \pm 2.36$ \\
\hline Uric acid (mg/dL) & $2.44 \pm 0.12$ & $5.45 \pm 0.87^{\mathrm{z}}$ & $2.49 \pm 0.12^{\mathrm{c}}$ & $2.34 \pm 0.15^{\mathrm{c}}$ & $2.88 \pm 0.14^{\mathrm{c}}$ & $2.31 \pm 0.14$ \\
\hline $\mathrm{Ca}^{2+}(\mathrm{mg} / \mathrm{dL})$ & $4.82 \pm 0.50$ & $1.94 \pm 0.15^{\mathrm{y}}$ & $4.43 \pm 0.37^{\mathrm{a}}$ & $4.34 \pm 0.67^{\mathrm{a}}$ & $4.21 \pm 0.78^{\mathrm{a}}$ & $4.66 \pm 0.54$ \\
\hline $\mathrm{K}^{+}(\mathrm{mEq} / \mathrm{L})$ & $5.44 \pm 0.25$ & $4.70 \pm 0.81$ & $5.20 \pm 0.36$ & $5.52 \pm 0.27$ & $5.92 \pm 0.49$ & $5.50 \pm 0.20$ \\
\hline $\mathrm{Na}^{+}(\mathrm{mEq} / \mathrm{L})$ & $140.80 \pm 1.15$ & $134.00 \pm 0.70$ & $142.60 \pm 0.67$ & $135.20 \pm 5.39$ & $143.40 \pm 0.50$ & $141.00 \pm 1.44$ \\
\hline $\mathrm{Cl}^{-}(\mathrm{mEq} / \mathrm{L})$ & $105.80 \pm 1.01$ & $104.20 \pm 1.20$ & $104.00 \pm 0.66$ & $108.20 \pm 0.96$ & $105.20 \pm 1.49$ & $105.00 \pm 1.14$ \\
\hline
\end{tabular}

Each value represents the mean \pm SEM. $n=6 ;{ }^{\mathrm{y}} p<0.01$ and $^{\mathrm{z}} p<0.001$ indicate significant differences as compared to normal control. ${ }^{\mathrm{a}} p<0.01$ and ${ }^{\mathrm{c}} p<0.001$ indicate significant differences as compared to negative control. $\mathrm{NC}=$ normal control, $\mathrm{GM}=$ gentamicin, $\mathrm{AECZ}=$ stem barks aqueous extract of Cinnamomum zeylanicum, and Sily $50=$ silymarin $(50 \mathrm{mg} / \mathrm{kg})$.

An intraperitoneal injection of rats with gentamicin $(100 \mathrm{mg} / \mathrm{kg})$ for 14 days decreased the content of GSH significantly by about $70.87 \%(43.40 \pm 5.43)$, compared to the normal control group $(168.00 \pm 11.01)$. Moreover, pretreatment with silymarin $(50 \mathrm{mg} / \mathrm{kg})$ or AECZ $200 \mathrm{mg} / \mathrm{kg}$ and $400 \mathrm{mg} / \mathrm{kg}$ one hour before gentamicin administration caused significant 2.3-, 3.2-, and 2.94-fold increases in renal glutathione content $(100.00 \pm 3.33,139.00 \pm 10.60$, and $128.01 \pm 7.91)$, respectively, compared with the gentamicin group $(43.40 \pm 5.43)$.

Gentamicin injection $(100 \mathrm{mg} / \mathrm{kg} /$ day $)$ for 14 days caused significant elevation $(p<0.01)$ of renal lipid peroxidation, which manifested as an increase in malondialdehyde concentration $(4.37 \pm 0.13)$, compared with the normal control group $(3.19 \pm 0.02)$. Pretreatment with silymarin $(50 \mathrm{mg} / \mathrm{kg})$ and AECZ $(200 \mathrm{mg} / \mathrm{kg}$ and $400 \mathrm{mg} / \mathrm{kg})$ for 14 days before gentamicin significantly reduced malondialdehyde concentration by about $38.58 \%, 38.21 \%$, and $37.75 \%$ reaching $2.64 \pm 0.21,2.70 \pm 0.33$, and $2.72 \pm 0.14$, respectively, in comparison with the gentamicin group $(4.37 \pm 0.13)$.

Gentamicin-treated rats (negative control) showed significant decrease of $27 \%(p<0.01)$ in kidney protein content as compared to normal control, whereas there was a significant increase in total protein content when animals were treated with silymarin $(60.27 \%, p<0.001)$, AECZ $200 \mathrm{mg} / \mathrm{kg}$ $(53.42 \%, p<0.001)$, and AECZ $400 \mathrm{mg} / \mathrm{kg}(35.61 \%, p<0.01)$ as compared to GM-treated rats.

The level of nitrite was increased significantly by $112.64 \%$ $(p<0.001)$ in gentamicin-treated rats as compared to normal rats. This concentration of nitrite was decreased significantly by $40.81 \%(p<0.01)$ in silymarin group, by $53.78 \%$ $(p<0.001)$ in AECZ $(200 \mathrm{mg} / \mathrm{kg})$ group, and by 47.02 $(p<0.001)$ in AECZ $(400 \mathrm{mg} / \mathrm{kg})$ group as compared to GMtreated rats.
3.6. Effect of the Aqueous Extract of C. zeylanicum Stem Bark on Proinflammatory Cytokines (TNF- $\alpha, I L-1 \beta$, and IL-6). As depicted in Figure 2, when compared to normal control group, GM administration induced a significant $(p<0.001)$ 2.21 -fold elevation of TNF- $\alpha(116.0 \pm 6.3$ to $257.0 \pm 18.9 \mathrm{pg} /$ $\mathrm{mg}$ of protein). However, when these animals were concomitantly treated with silymarin $(50 \mathrm{mg} / \mathrm{kg})$ and GM, a 1.43 -fold significant $(p<0.001)$ decrease in the TNF- $\alpha$ levels was noted. In groups treated with AECZ at the doses of 200 and $400 \mathrm{mg} / \mathrm{kg}, 1.34$-fold and 1.70 -fold decreases of the TNF- $\alpha$ levels were, respectively, observed.

GM administration induced a significant $(p<0.001)$ 2.17-fold elevation of IL-6 (from $39.3 \pm 1.72$ to $85.4 \pm 3.45 \mathrm{pg} / \mathrm{mg}$ of protein) when compared to normal control rats. As compared to the GM-treated rats, silymarin $(50 \mathrm{mg} / \mathrm{kg})$ significantly $(p<0.001)$ decreased the IL-6 levels by 1.81 folds. In groups treated by AECZ at the doses of 200 and $400 \mathrm{mg} / \mathrm{kg}$, significant $(p<0.001) 1.58$-fold and 1.86 -fold decreases of the IL- 6 level were, respectively, observed.

Figure 2 also shows the effects of AECZ and silymarin on the levels of IL- $1 \beta$ in GM-treated rats. When compared to normal control rats, gentamicin induced a 2.26 -fold significant $(p<0.001$ ) elevation of IL-1 $\beta$ (from $22.9 \pm 1.31$ to $51.9 \pm 1.6 \mathrm{pg} / \mathrm{mg}$ of protein).

As compared to GM group, silymarin $(50 \mathrm{mg} / \mathrm{kg})$ significantly $(p<0.001)$ decreased the IL-1 $\beta$ levels by 1.37 folds (from $51.9 \pm 1.6$ to $37.8 \pm 1.85 \mathrm{pg} / \mathrm{mg}$ of protein). Treatment with AECZ at the doses of 200 and $400 \mathrm{mg} / \mathrm{kg}$ significantly decreased the level of IL- $1 \beta$, respectively, by 1.40 folds $(p<0.01)$ and 1.66 folds $(p<0.001)$.

AECZ administered alone at the dose of $400 \mathrm{mg} / \mathrm{kg}$ did not significantly affect the cytokines' content, although a slight increase in IL- $1 \beta$ level was noted, when compared to the normal control. 


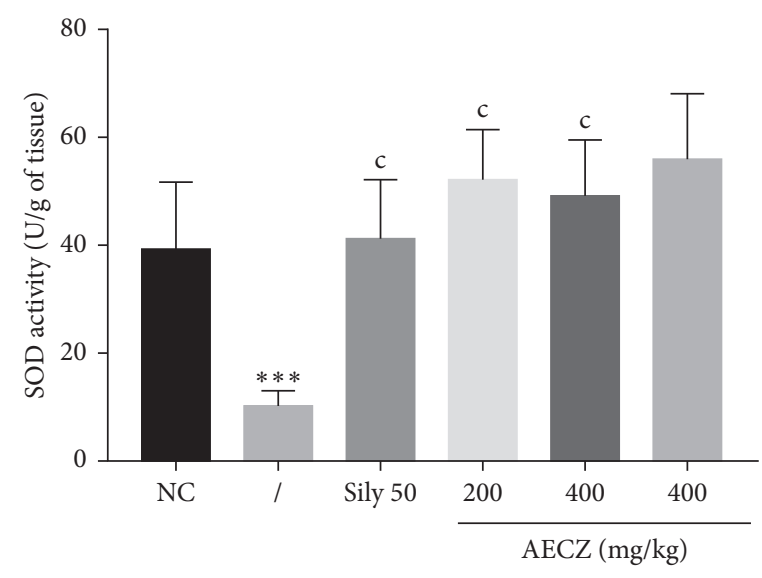

Gentamicin (100mg/kg)

(a)

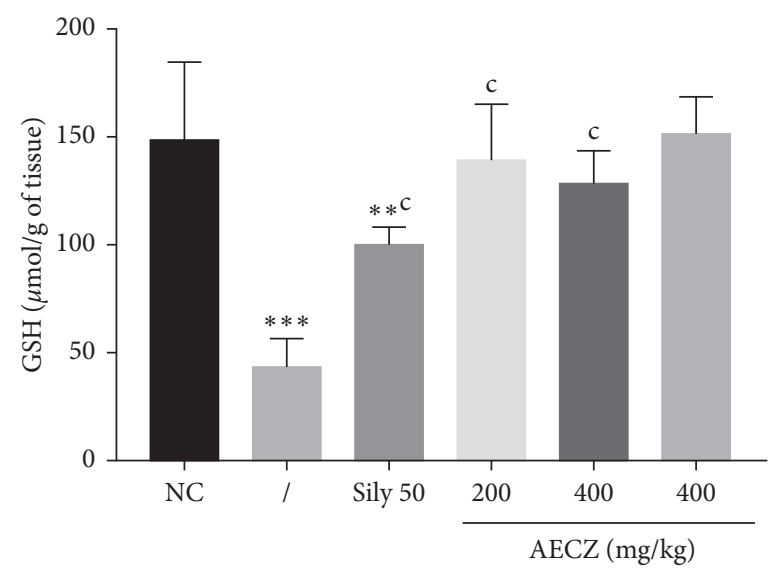

Gentamicin (100 mg/kg)

(c)

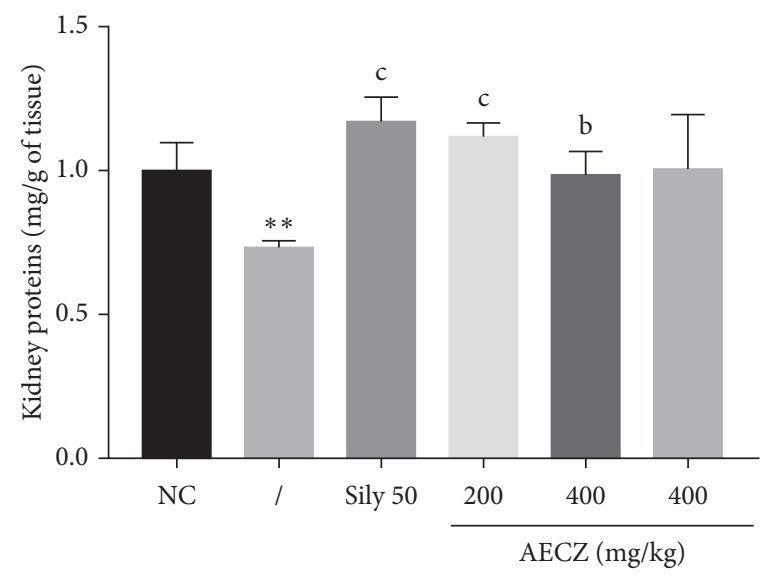

Gentamicin (100 mg/kg)

(e)

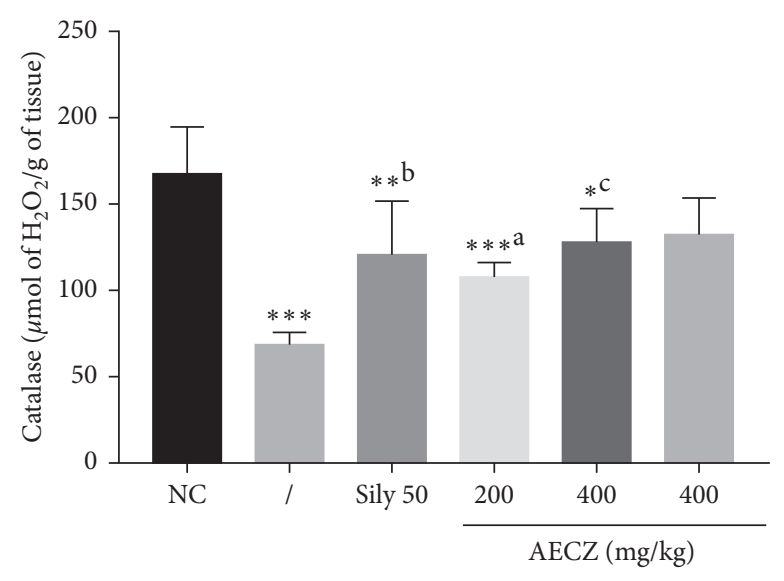

Gentamicin $(100 \mathrm{mg} / \mathrm{kg})$

(b)

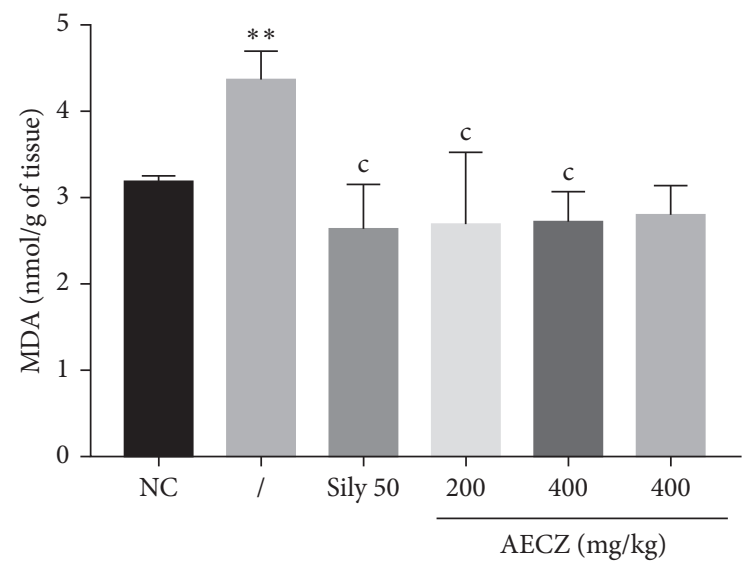

Gentamicin $(100 \mathrm{mg} / \mathrm{kg})$

(d)

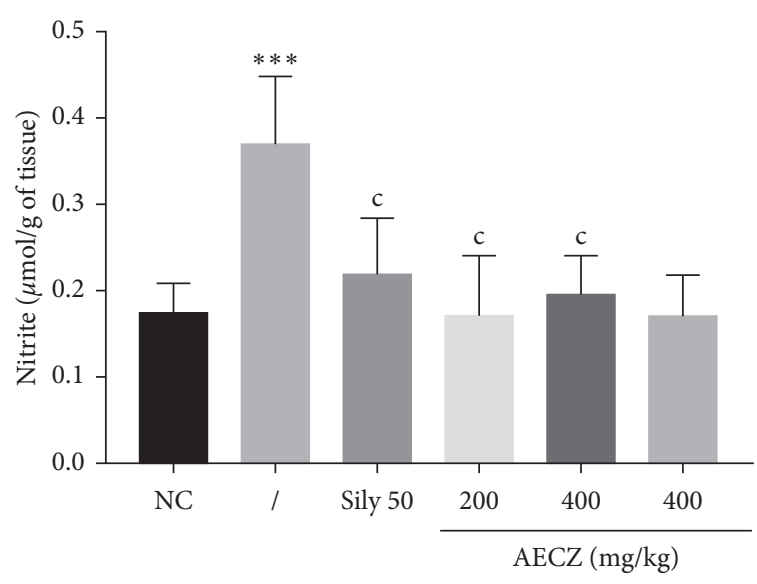

Gentamicin $(100 \mathrm{mg} / \mathrm{kg})$

(f)

FIGURE 1: Effects of Cinnamomum zeylanicum stem bark aqueous extract on kidney's oxidative stress parameters. Each bar represents the mean \pm SEM. $n=6 ;^{*} p<0.05,{ }^{* *} p<0.01$, and ${ }^{* * *} p<0.001$ indicate significant differences as compared to normal control. ${ }^{a} p<0.05$, ${ }^{\mathrm{b}} p<0.01$, and ${ }^{\mathrm{c}} p<0.001$ indicate significant differences as compared to the gentamicin group. NC: normal control, AECZ: stem bark aqueous extract of Cinnamomum zeylanicum, and Sily $50=$ silymarin $(50 \mathrm{mg} / \mathrm{kg}$ ). (a) Superoxide dismutase. (b) Catalase. (c) Reduced glutathione. (d) Lipid peroxidation. (e) Proteins. (f) Nitrites. 


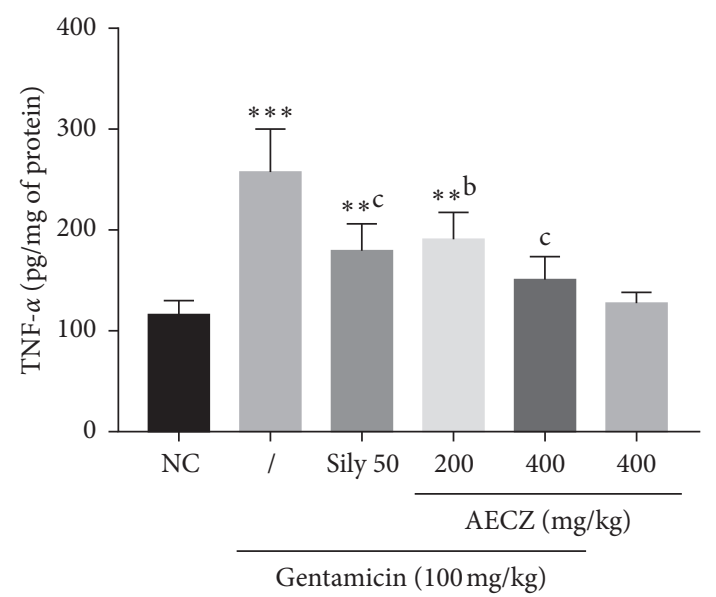

(a)

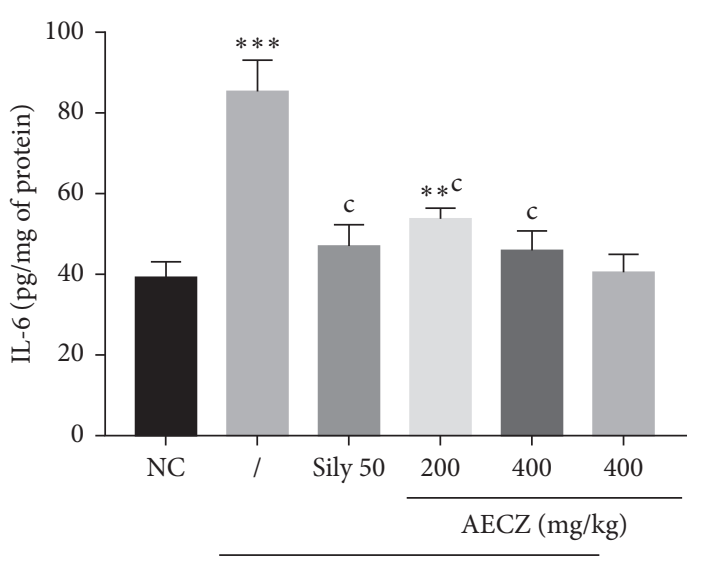

Gentamicin $(100 \mathrm{mg} / \mathrm{kg})$

(b)

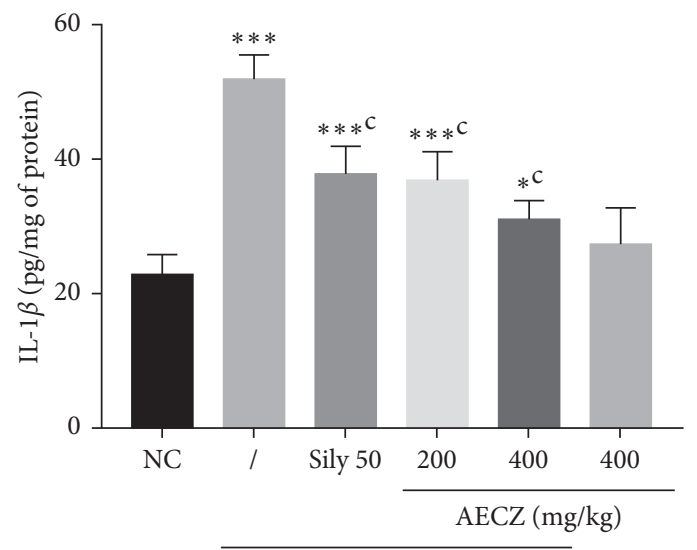

Gentamicin (100 mg/kg)

(c)

Figure 2: Effects of Cinnamomum zeylanicum stem bark aqueous extract on proinflammatory cytokines. Each bar represents the mean \pm SEM. $n=6$; ${ }^{*} p<0.05,{ }^{* *} p<0.01$, and ${ }^{* * *} p<0.001$ indicate significant differences as compared to normal control. ${ }^{\mathrm{b}} p<0.01$ and ${ }^{c} p<0.001$ indicate significant differences as compared to the gentamicin group. NC: normal control, AECZ: stem barks aqueous extract of Cinnamomum zeylanicum, and Sily $50=$ silymarin $(50 \mathrm{mg} / \mathrm{kg}$ ). (a) Tumor necrosis factor-alpha. (b) Interleukin-6. (c) Interleukin-1-beta.

3.7. Effects of C. zeylanicum Aqueous Extract on Renal Histology. Microscopically, kidney sections from control rats revealed the normal structure of renal parenchyma (Figure 3(a)). The kidney of rats in negative control group (Figure 3(a)) presented many structural alterations including leucocytes infiltration (inflammation), tubular necrosis, tubular clarification, cilia loss, glomerular degeneration, mesangial expansion, and significant reduction of urinary space. The architecture of the kidney of rats treated with AECZ at the doses of $200 \mathrm{mg} / \mathrm{kg}$ and $400 \mathrm{mg} / \mathrm{kg}$ as well as silymarin (Figure 3(a)) showed no histopathological alterations as compared to normal control group. Compared to the normal control group, gentamicin induced significant $(p<0.001)$ increase of tubular clarification (Figure 3(b)). The treatment with AECZ (200 and $400 \mathrm{mg} / \mathrm{kg}$ ) as well as silymarin $(50 \mathrm{mg} / \mathrm{kg})$ reduced significantly $(p<0.001)$ this damage (Figure 3(b)).

\section{Discussion}

The purpose of this work was to evaluate the potential nephroprotective activity of the lyophilized aqueous extract of Cinnamomum zeylanicum stem bark in gentamicin-induced nephrotoxicity. AECZ and silymarin treatments prevented gentamicin's deleterious effects such as decrease in body weight, serum total proteins, and calcium level and increase in kidneys' relative weight, serum creatinine, urea, and uric acid. AECZ and silymarin also reduced oxidative stress status by increasing the levels of reduced glutathione, catalase, and superoxide dismutase activities and decreasing malondialdehyde, proinflammatory cytokines (TNF- $\alpha$, IL$1 \beta$, and IL-6), and nitrites compared to gentamicin-treated group. Histological analysis of the kidney revealed that AECZ prevented kidney alterations induced by gentamicin.

Gentamicin has been intensively used as an experimental model of nephrotoxicity as it perfectly reflects clinical cases. The main aspect of gentamicin nephrotoxicity is tubular cytotoxicity. In fact, it causes tubular damage through necrosis of tubular epithelial cells predominantly in proximal segment and alteration of function of main cellular components involved in transport of water and solutes. In the present study, 14 days of gentamicin injection reduced body weight gain and increased the kidney's relative weight. The 


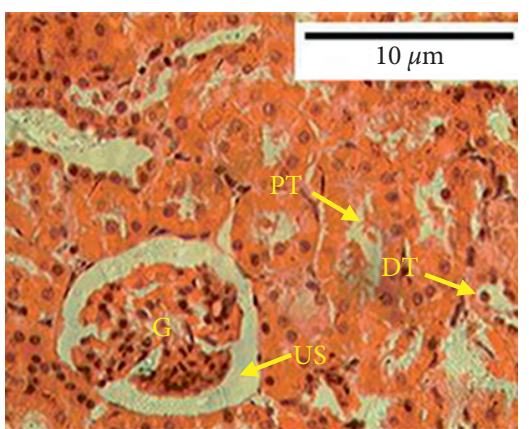

Normal control

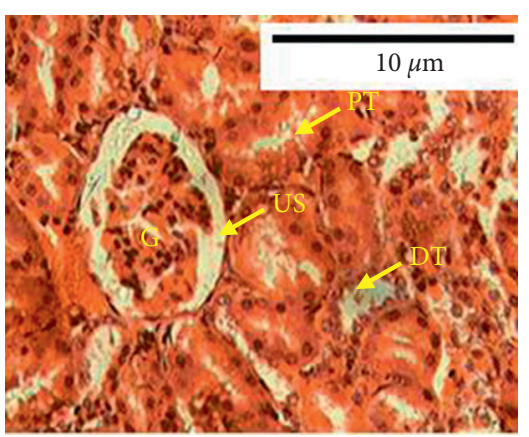

AECZ $200+$ GM

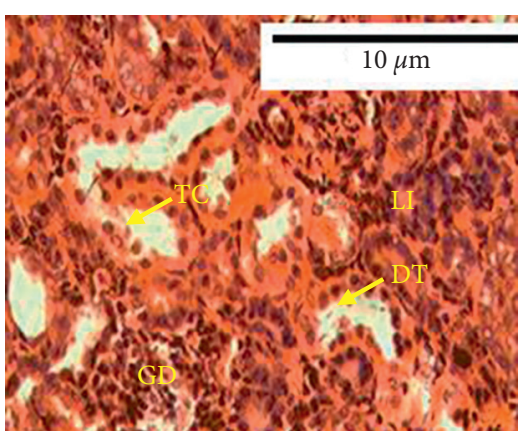

Negative control (GM)

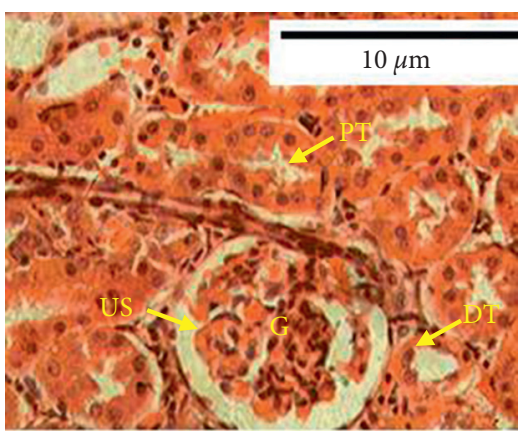

AECZ $400+$ GM

(a)

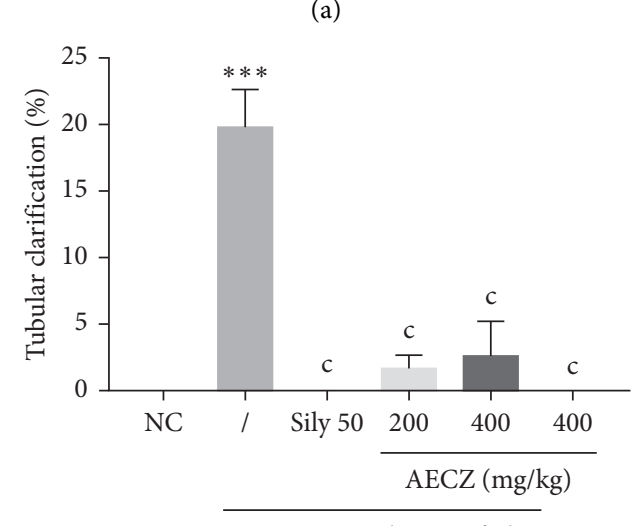

Gentamicin $(100 \mathrm{mg} / \mathrm{kg})$

(b)

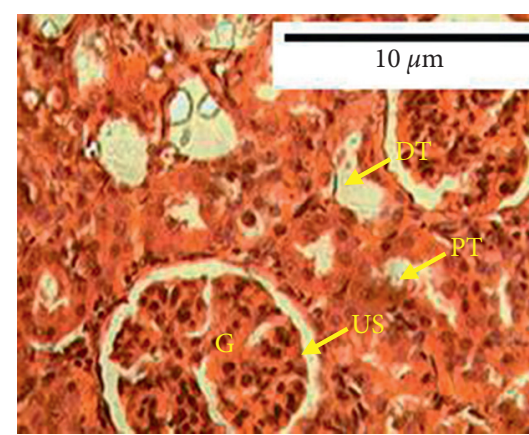

Positive control (Sily $50+$ GM)

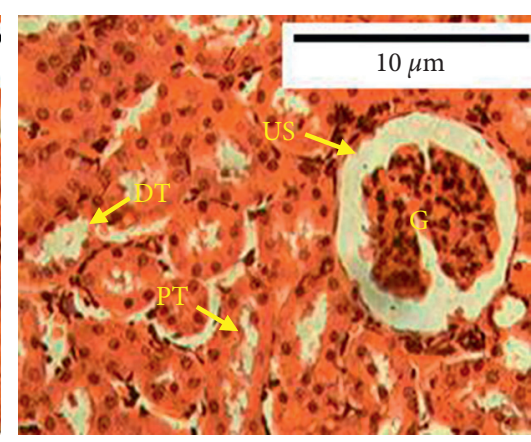

AECZ 400 alone

Figure 3: (a) Microphotographs of the kidney tissue $(H \& E, \times 400)$ and $(b)$ the percentage of tubular clarification. Each bar represents the mean \pm SEM. $n=6$; ${ }^{* * *} p<0.001$ indicates significant difference as compared to normal control. ${ }^{c} p<0.001$ indicates significant difference as compared to the gentamicin group. NC: normal control, AECZ: stem barks aqueous extract of Cinnamomum zeylanicum, Sily $50=$ silymarin (50 mg/kg), G: glomeruli, US: urinary space, PT: proximal tubule, DT: distal tubule, LI: leucocyte infiltrations, TC: tubular clarification, GD: glomerular degeneration, and GM: gentamicin.

decrease of body weight gain could be a result of increased proteolysis and reduced proteins synthesis as previously demonstrated [35-37]. The proteolysis and reduced proteins synthesis were confirmed in this study through the decrease of the level of total proteins in the serum and kidneys of gentamicin-treated animal. AECZ significantly prevented the loss in body weight induced by gentamicin. Moreover, the animal treated with AECZ alone showed significantly higher weight compared to the normal control. It could then be suggested that AECZ prevents proteolysis or even potentiate protein synthesis. The hypothesis of inhibition of proteolysis is supported by the fact that AECZ significantly prevented the drop in serum protein content induced by gentamicin. However, the plant extract was unable to increase the serum protein concentration when administered alone, rolling out its probable effect on protein synthesis.

Oxidative stress activation and inflammatory process constitute a major part of gentamicin nephrotoxicity. In fact, nephrotoxicity induced by gentamicin is associated with the mitochondrial dysfunction in renal tubular cells. It causes a marked impairment in the activity of mitochondrial respiratory enzymes including $\mathrm{NADH}$ dehydrogenase resulting in the excessive ROS generation [38]. Furthermore, gentamicin has been reported to stimulate $\mathrm{O}_{2}{ }^{-}$and $\mathrm{NO}^{\bullet}$ generation through activation of inducible isoform of $\mathrm{NO}^{\bullet}$ synthase (iNOS) in kidney [39] tissue. Reactive free radicals 
result in the lipid peroxidation, leading to the alteration of membrane lipid bilayer arrangement and reduction in antioxidant defense mechanisms, causing cellular damage and necrosis [39, 40]. AECZ significantly reduced the oxidative/ nitrosative stress markers such as MDA and $\mathrm{NO}^{\bullet}$ and further boosted the endogenous antioxidant parameters including SOD, catalase, and GSH, suggesting its in vivo antioxidant effects. This antioxidant effect of AECZ might contribute to its nephroprotective activity.

For more insight into the beneficial effects of AECZ, we evaluated additional parameters of nephron-cytotoxicity and renal function. Gentamicin induced significant increase in the blood levels of creatinine, urea, uric acid, albumin, and ASAT, indicating renal necrosis and dysfunction [1, 41]. Administration of AECZ or silymarin along with gentamicin caused significant decrease in these parameters. These results suggest that AECZ is able to protect the renal function and give additional evidence of nephroprotection.

The development of oxidative stress coupled with the necrosis triggers the inflammatory process [39, 40]. Inflammation was evidenced in gentamicin-treated animals by a drastic increase in proinflammatory cytokines (TNF- $\alpha$, IL$1 \beta$, and IL-6).

The role of these proinflammatory mediators is well known in the kidney diseases [34, 42]. In this study, AECZ and silymarin significantly downregulate the renal proinflammatory cytokines, demonstrating the anti-inflammatory effect of this plant extract. These findings corroborate those of earlier studies, which proved that plant extracts are able to reverse the increase of proinflammatory cytokines levels induced by gentamicin [42-44]. Previous study on the hydroalcoholic extract of Cinnamomum zeylanicum stem bark on nociception and anxiety demonstrated that the antiinflammatory effect is ascribed to trans-cinnamaldehyde component of cinnamon [25,45].

Any toxic substance that triggers good functioning of the kidney provokes an inflammatory response in the kidney tissue, as well as its hypertrophy $[46,47]$; the increase of the kidney's relative weight observed in animal group that received gentamicin could have probably resulted from the edema that was caused by drug-induced acute tubular necrosis. The plant extract as well as silymarin significantly mitigated the kidney hypertrophy. This may result from the anti-inflammatory potential of AECZ.

The haematopoietic system is one of the most sensitive targets for toxic compounds and an important index of physiological and pathological status in man and animal. Surprisingly, apart from the monocytes whose number decreased in animals treated with gentamicin, no other hematological parameter varied significantly independently of the treatment. This fact remains to be understood.

Aminoglycosides cause disturbance of renal functions by accumulating on the membranes of the proximal convoluted tubule, impairing the reabsorption and secretion of electrolytes and in that way causing homeostatic imbalance. In the present study, serum calcium level was reduced significantly and a nonsignificant decrease in serum sodium and potassium levels in gentamicin-treated rats was observed. These observations on serum sodium and potassium levels, although nonsignificant, are in agreement with those of Nafiu et al. [48] showing that serum sodium and potassium reduction was observed in gentamicin-treated rats, indicative of lesions in renal tubular epithelium and despair of $\mathrm{Na}^{+}$/ $\mathrm{K}^{+}$-ATPase by gentamicin. Studies in animal and human have demonstrated that gentamicin and other aminoglycosides impair calcium transport in the renal tubules and, in some instances, result in a significant increase in urinary calcium excretion and in that way cause hypocalcemia [36]. AECZ as well as silymarin inhibited the decrease of serum calcium level in this study.

Evidences have indicated that the renal toxicity of gentamicin is due to its selective accumulation in the renal proximal convoluted tubules, which subsequently leads to the loss of the tubule brush border integrity, severe degeneration, necrosis in epithelial cells of the proximal tubules, and infiltration of mononuclear cells in intertubular spaces [4, 49]. In this study, the histological analyses of kidney sections from gentamicin-treated animals (negative control) showed inflammations, fibrosis, tubular clarifications, glomerular hypertrophy, and degeneration with a reduced urinary space. Previous studies described this renal tissue damage induced by gentamicin as well [36, 47]. The histological analysis of kidney sections from animals treated with AECZ or silymarin presented an aspect that is similar to that of normal animals. Compared to the normal control group, gentamicin induced significant increase of tubular clarification. The treatment with AECZ (200 and $400 \mathrm{mg} / \mathrm{kg}$ ) as well as silymarin $(50 \mathrm{mg} / \mathrm{kg})$ reduced significantly this damage. This shows that AECZ prevented the damage of renal tissues by gentamicin. These histopathological observations correlate with the biochemical values. The animals that were treated with AECZ ( $400 \mathrm{mg} / \mathrm{kg}$ ) alone showed no pathological changes. This indicates that AECZ does not possess any adverse effects. Interestingly, the two major constituents of Cinnamomum zeylanicum stem bark are cinnamaldehyde and eugenol. It has been well documented that they have various therapeutic properties like antioxidative and anti-inflammatory properties, as well as nephroprotective effects $[25,50-52]$. Thus, the nephroprotective effect observed in the present study might be due to the presence of cinnamaldehyde and eugenol [45].

\section{Conclusion}

Data from the present study evidenced the nephroprotective effect of AECZ against gentamicin toxicity and further support the use of this plant by the local populations in the management of kidney diseases. The nephroprotective effect of AECZ is more likely mediated by its antioxidant and antiinflammatory capacities. AECZ might be a good candidate for the development of new drugs that can protect against acute kidney diseases.

\section{Abbreviations}

AECZ: Cinnamomum zeylanicum stem bark aqueous extract

ANOVA: One-way analysis of variance 


$\begin{array}{ll}\text { ASAT: } & \text { Aspartate aminotransferase } \\ \text { CAT: } & \text { Catalase } \\ \text { GD: } & \text { Glomerular degeneration } \\ \text { DT: } & \text { Distal tubule } \\ \text { EDTA: } & \text { Ethylenediaminetetraacetic acid } \\ \text { G: } & \text { Glomeruli } \\ \text { GM: } & \text { Gentamicin } \\ \text { GSH: } & \text { Reduced glutathione } \\ \text { H\&E: } & \text { Hematoxylin and eosin } \\ \text { Hb: } & \text { Hemoglobin } \\ \text { HCT: } & \text { Hematocrit } \\ \text { IL: } & \text { Interleukin } \\ \text { LI: } & \text { Leucocyte infiltrations } \\ \text { MDA: } & \text { Malondialdehyde } \\ \text { NF- } \kappa \text { B: } & \text { Nuclear factor-kappa B } \\ \text { NO: } & \text { Nitric oxide } \\ \text { PT: } & \text { Proximal tubule } \\ \text { RBC: } & \text { Red blood cell } \\ \text { ROS: } & \text { Reactive oxygen species } \\ \text { SEM: } & \text { Standard error of mean } \\ \text { Sily 50: } & \text { Silymarin (50 mg/kg) } \\ \text { SOD: } & \text { Superoxide dismutase } \\ \text { TC: } & \text { Tubular clarification } \\ \text { TNF- } \alpha: & \text { Tumor necrosis factor-alpha } \\ \text { UK: } & \text { United Kingdom } \\ \text { US: } & \text { Urinary space } \\ \text { USA: } & \text { United States of America } \\ \text { WBC: } & \text { White blood cell. } \\ & \end{array}$

\section{Data Availability}

All data supporting our findings are adequately contained within the manuscript.

\section{Ethical Approval}

All the procedures and protocols involving animals and their care were conducted in conformity with the institutional guidelines approved by the Cameroon National Ethical Committee (reg. no. FWA-IRB00001954). All efforts were made to minimize animal suffering and to reduce the number of animals used.

\section{Conflicts of Interest}

The authors declare that they have no conflicts of interest.

\section{Authors' Contributions}

Albert Donatien Atsamo, Auscar Lontsie Songmene, and Mireille Flaure Metchi Donfack designed the work. Albert Donatien Atsamo, Auscar Lontsie Songmene, Mireille Flaure Metchi Donfack, and Omer Bébé Ngouateu conducted the work and collected and analyzed the data. Albert Donatien Atsamo, Auscar Lontsie Songmene, Nguelefack Télesphore Benoît, and Théophile Dimo drafted the manuscript and revised it critically. All authors read and approved the final version of the manuscript.

\section{Acknowledgments}

The authors acknowledge the Faculty of Sciences, University of Yaoundé, Cameroon, for providing the facilities to carry out this research work. The authors also thank researchsquare.com which popularized this work for more visibility and criticism.

\section{References}

[1] J. Safa, H. Argani, B. Bastani et al., "Protective effect of grape seed extract on gentamicin-induced acute kidney injury," Iranian Journal of Kidney Diseases, vol. 4, no. 4, pp. 285-291, 2010.

[2] M. R. Khan, I. Badar, and A. Siddiquah, "Prevention of hepatorenal toxicity with Sonchus asper in gentamicin treated rats," BMC Complementary and Alternative Medicine, vol. 11, no. 113, 2011.

[3] N. Ullah, M. Azam Khan, T. Khan, and W. Ahmad, "Protective potential of Tamarindus indicaagainst gentamicininduced nephrotoxicity," Pharmaceutical Biology, vol. 52, no. 4, pp. 428-434, 2014.

[4] J. M. Lopez-Novoa, Y. Quiros, L. Vicente, A. I. Morales, and F. J. Lopez-Hernandez, "New insights into the mechanism of aminoglycoside nephrotoxicity: an integrative point of view," Kidney International, vol. 79, no. 1, pp. 33-45, 2011.

[5] S. Kalayarasan, P. N. Prabhu, N. Sriram et al., "Diallyl sulfide enhances antioxidants and inhibits inflammation through the activation of Nrf2 against gentamicin-induced nephrotoxicity in Wistar rats," European Journal of Pharmacology, vol. 606, no. 1-3, pp. 162-171, 2009.

[6] P. Balakumar, A. Rohilla, and A. Thangathirupathi, "Gentamicin-induced nephrotoxicity: do we have a promising therapeutic approach to blunt it?" Pharmacological Research, vol. 62 , no. 3, 2010.

[7] I.-C. Lee, S.-H. Kim, S.-M. Lee et al., "Melatonin attenuates gentamicin-induced nephrotoxicity and oxidative stress in rats," Archives of Toxicology, vol. 86, no. 10, pp. 1527-1536, 2012.

[8] A. S. Abdel-Azeem, A. M. Hegazy, H. M. Zeidan, K. S. Ibrahim, and E. M. El-Sayed, "Potential renoprotective effects of rosemary and thyme against gentamicin toxicity in rats," Journal of Dietary Supplements, vol. 14, no. 4, pp. 380-394, 2017.

[9] A. O. Nafiu, R. O. Akomolafe, Q. K. Alabi, C. O. Idowu, and O. O. Odujoko, "Effect of fatty acids from ethanol extract of Moringa oleifera seeds on kidney function impairment and oxidative stress induced by gentamicin in rats," Biomedicine \& Pharmacotherapy, vol. 117, Article ID 109154, 2019.

[10] A. Kostermans, "The south Indian species of cinnamomum schaeffer (lauraceae)," Nelumbo, vol. 25, no. 1-4, pp. 90-133, 1983.

[11] M. K. Balijepalli, A. S. Buru, R. Sakirolla, and M. R. A. O. Pichika, "Cinnamomum genus: a review on its biological activities," International Journal of Pharmacy and Pharmaceutical Sciences, vol. 9, no. 2, pp. 1-11, 2017.

[12] J. P. M. Dongmo, L. N. Tatsadjieu, F. Tchoumbougnang et al., "Chemical composition, antiradical and antifungal activities of essential oil of the leaves of cinnamomum zeylanicum blume from Cameroon," Natural Product Communications, vol. 2, no. 12, pp. 1287-1290, 2007.

[13] P. Nyadjeu, A. Dongmo, T. B. Nguelefack, and A. Kamanyi, "Antihypertensive and vasorelaxant effects of cinnamomum zeylanicum stem bark aqueous extract in rats," Journal of Complementary \& Integrative Medicine, vol. 8, no. 1, 2011. 
[14] A. H. Atta and A. Alkofahi, "Anti-nociceptive and anti-inflammatory effects of some Jordanian medicinal plant extracts," Journal of Ethnopharmacology, vol. 60, no. 2, pp. 117-124, 1998.

[15] E. J. Verspohl, K. Bauer, and E. Neddermann, “Antidiabetic effect of Cinnamomum cassia and Cinnamomum zeylanicum in vivo and in vitro," Phytotherapy Research, vol. 19, no. 3, pp. 203-206, 2005.

[16] S. R. Niphade, M. Asad, G. K. Chandrakala, E. Toppo, and P. Deshmukh, "Immunomodulatory activity ofCinnamomum zeylanicumbark," Pharmaceutical Biology, vol. 47, no. 12, pp. 1168-1173, 2009.

[17] I. M. Nagendra Nayak, C. Rajasekhar, and R. Jetti, "Antiatherosclerotic potential of aqueous extract of Cinnamomum zeylanicum bark against glucocorticoid induced atherosclerosis in wistar rats," Journal of Clinical and Diagnostic Research, vol. 11, no. 5, pp. FC19-FC23, 2017.

[18] P. Nyadjeu, E. P. Nguelefack-Mbuyo, A. D. Atsamo, T. B Nguelefack, A. B Dongmo, and A Kamanyi, "Acute and chronic antihypertensive effects of Cinnamomum zeylanicum stem bark methanol extract in L-NAME-induced hypertensive rats," BMC Complementary and Alternative Medicine, vol. 13, no. Jan, p. 27, 2013.

[19] G. E. Elshopakey and S. T. Elazab, "Cinnamon aqueous extract attenuates diclofenac sodium and oxytetracycline mediated hepato-renal toxicity and modulates oxidative stress, cell apoptosis, and inflammation in male albino rats," Veterinary Sciences, vol. 8, no. 1, pp. 1-19, 2021.

[20] S. Alshahrani, M. Ashafaq, S. Hussain et al., "Renoprotective effects of cinnamon oil against APAP-Induced nephrotoxicity by ameliorating oxidative stress, apoptosis and inflammation in rats," Saudi Pharmaceutical Journal, vol. 29, no. 2, pp. 194-200, 2021.

[21] M. Vangalapati, N. Sree Satya, D. V. Surya Prakash, and S. Avanigadda, "A review on pharmacological activities and clinical effects of Cinnamon species," Research Journal of Pharmaceutical, Biological and Chemical Sciences, vol. 3, no. 1, pp. 653-663, 2012.

[22] Y. Shen, L.-N. Jia, N. Honma, T. Hosono, T. Ariga, and T. Seki, "Beneficial effects of cinnamon on the metabolic syndrome, inflammation, and pain, and mechanisms underlying these effects-a review," Journal of Traditional and Complementary Medicine, vol. 2, no. 1, pp. 27-32, 2012.

[23] R. A. Anderson, C. L. Broadhurst, M. M. Polansky et al., "Isolation and characterization of polyphenol type-a polymers from cinnamon with insulin-like biological activity," Journal of Agricultural and Food Chemistry, vol. 52, no. 1, pp. 65-70, 2004.

[24] M. M. Said, "The protective effect of eugenol against gentamicin-induced nephrotoxicity and oxidative damage in rat kidney," Fundamental \& Clinical Pharmacology, vol. 25, no. 6, pp. 708-716, 2011.

[25] L. K. Chao, K.-F. Hua, H.-Y. Hsu et al., "Cinnamaldehyde inhibits pro-inflammatory cytokines secretion from monocytes/macrophages through suppression of intracellular signaling," Food and Chemical Toxicology, vol. 46, no. 1, pp. 220-231, 2008.

[26] P. Khuwijitjaru, N. Sayputikasikorn, S. Samuhasaneetoo, P. Penroj, P. Siriwongwilaichat, and S. Adachi, "Subcritical water extraction of flavoring and phenolic compounds from cinnamon bark (Cinnamomum zeylanicum)," Journal of Oleo Science, vol. 61, no. 6, pp. 349-355, 2012.

[27] N. Ullah, M. Azam Khan, T. Khan, and W. Ahmad, "Bioactive traditional plant Cinnamomum zeylanicum successfully combat against nephrotoxic effects of aminoglycosides," Bangladesh Journal of Pharmacology, vol. 8, no. 1, pp. 15-21, 2013.

[28] A. Abdeen, A. Abdelkader, M. Abdo et al., "Protective effect of cinnamon against acetaminophen-mediated cellular damage and apoptosis in renal tissue," Environmental Science and Pollution Research, vol. 26, no. 1, pp. 240-249, 2019.

[29] M. M. Bradford, "A rapid and sensitive method for the quantitation of microgram quantities of protein utilizing the principle of protein-dye binding," Analytical Biochemistry, vol. 72 , no. $1-2$, pp. $248-254,1976$.

[30] G. L. Ellman, "Tissue sulfhydryl groups," Archives of Biochemistry and Biophysics, vol. 82, no. 1, pp. 70-77, 1959.

[31] A. K. Sinha, "Colorimetric assay of catalase," Analytical Biochemistry, vol. 47, no. 2, pp. 389-394, 1972.

[32] P. Slack, Analytical Methods Manual, Leatherhead Food Research Association, Leatherhead, UK, 2nd edition, 1987.

[33] K. M. Wilbur, F. Bernheim, and O. W. Shapiro, "The thiobarbituric acid reagent as a test for the oxidation of unsaturated fatty acids by various agents," Archives of Biochemistry, vol. 24, no. 2, pp. 305-313, 1949.

[34] A. A. El Gamal, M. S. Alsaid, M. Raish et al., "Beetroot (Beta vulgaris L.) extract ameliorates gentamicin-induced nephrotoxicity associated oxidative stress, inflammation, and apoptosis in rodent model," Mediators of Inflammation, vol. 2014, Article ID 983952, 12 pages, 2014.

[35] M. Adil, A. D. Kandhare, G. Dalvi et al., "Ameliorative effect of berberine against gentamicin-induced nephrotoxicity in rats via attenuation of oxidative stress, inflammation, apoptosis and mitochondrial dysfunction," Renal Failure, vol. 38, no. 6, pp. 996-1006, 2016.

[36] P. Randjelović, S. Veljković, N. Stojiljković, D. Sokolović, and I. Ilić, "Gentamicin nephrotoxicity in animals: current knowledge and future perspectives," EXCLI Journal, vol. 16, 2017.

[37] T. Horibe, H. Matsui, M. Tanaka et al., "Gentamicin binds to the lectin site of calreticulin and inhibits its chaperone activity," Biochemical and Biophysical Research Communications, vol. 323, no. 1, pp. 281-287, 2004.

[38] B. D. Sahu, S. Tatireddy, M. Koneru et al., "Naringin ameliorates gentamicin-induced nephrotoxicity and associated mitochondrial dysfunction, apoptosis and inflammation in rats: possible mechanism of nephroprotection," Toxicology and Applied Pharmacology, vol. 277, no. 1, pp. 8-20, 2014.

[39] F. Paquette, A. Bernier-Jean, V. Brunette et al., "Acute kidney injury and renal recovery with the use of aminoglycosides: a large retrospective study," Nephron, vol. 131, no. 3, pp. 153-160, 2015.

[40] E. Birben, U. M. Sahiner, C. Sackesen, S. Erzurum, and O. Kalayci, "Oxidative stress and antioxidant defense," World Allergy Organization Journal, vol. 5, no. 1, pp. 9-19, 2012.

[41] A. Jain and A. K. Singhai, "Effect of Momordica dioicaRoxb on gentamicin model of acute renal failure," Natural Product Research, vol. 24, no. 15, pp. 1379-1389, 2010.

[42] S. P. Jose, A. S, K. Im et al., "Nephro-protective effect of a novel formulation of unopened coconut inflorescence sap powder on gentamicin induced renal damage by modulating oxidative stress and inflammatory markers," Biomedicine \& Pharmacotherapy, vol. 85, pp. 128-135, 2017.

[43] K. Joshi, S. Awte, P. Bhatnagar et al., "Cinnamomum zeylanicum extract inhibits proinflammatory cytokine TNF $\alpha$ : in vitro and in vivo studies," Research In Pharmaceutical Biotechnology, vol. 2, no. 2, pp. 14-21, 2010.

[44] H. Erjaee, F. Azma, and S. Nazifi, "Effect of caraway on gentamicin-induced oxidative stress, inflammation and 
nephrotoxicity in rats," Veterinary Science Development, vol. 5, no. 1, 2015.

[45] J. Sparsh Gupta and G. Sparsh, "Effects of Cinnamomum zeylanicum bark extract on nociception and anxiety like behavior in mice," Asian Journal of Pharmaceutical and Clinical Research, vol. 12, pp. 236-241, 2019.

[46] P. Witthawaskul, A. Panthong, D. Kanjanapothi, T. Taesothikul, and N. Lertprasertsuke, "Acute and subacute toxicities of the saponin mixture isolated from Schefflera leucantha Viguier," Journal of Ethnopharmacology, vol. 89, no. 1, pp. 115-121, 2003.

[47] J. B. Dhodi, D. R. Thanekar, S. N. Mestry, and A. R. Juvekar, "Carissa carandas Linn. fruit extract ameliorates gentamicininduced nephrotoxicity in rats via attenuation of oxidative stress," Journal of Acute Disease, vol. 4, no. 2, pp. 135-140, 2015.

[48] A. O. Nafiu, R. O. Akomolafe, Q. K. Alabi, C. O. Idowu, and O. O. Odujoko, "Effect of fatty acids from ethanol extract of Moringa oleifera seeds on kidney function impairment and oxidative stress induced by gentamicin in rats," Biomedicine \& Pharmacotherapy, vol. 117, 2019.

[49] S. Raju, S. Kavimani, V. Uma Maheshwara rao, K. Sreeramulu Reddy, and G. Vasanth Kumar, "Floral extract of Tecoma stans: a potent inhibitor of gentamicin-induced nephrotoxicity in vivo," Asian Pacific Journal of Tropical Medicine, vol. 4, no. 9, pp. 680-685, 2011.

[50] D. Gunawardena, N. Karunaweera, S. Lee et al., "Anti-inflammatory activity of cinnamon (C. zeylanicum and C. cassia) extracts-identification of E-cinnamaldehyde and o-methoxy cinnamaldehyde as the most potent bioactive compounds," Food \& Function, vol. 6, no. 3, pp. 910-919, 2015.

[51] E.-S. M. El-Sayed, O. M. Abd El-Raouf, H. M. Fawzy, and M. F. Manie, "Comparative study of the possible protective effects of cinnamic acid and cinnamaldehyde on cisplatininduced nephrotoxicity in rats," Journal of Biochemical and Molecular Toxicology, vol. 27, no. 12, pp. 508-514, 2013.

[52] J. N. Barboza, C. da Silva Maia Bezerra Filho, R. O. Silva, J. V. R. Medeiros, and D. P. de Sousa, "An overview on the anti-inflammatory potential and antioxidant profile of eugenol," Oxidative Medicine and Cellular Longevity, vol. 2018, Article ID 3957262, 9 pages, 2018. 